Abstracta Iranica Abstracta Iranica

Revue bibliographique pour le domaine irano-aryen

Volume 27 | 2006

Comptes rendus des publications de 2004

\title{
« Rhodes, Cyprus and Southern Anatolia During the Archaic and Achaemenid Periods: The Ionian Question ». Colloquium Anatolicum III, 2004, pp. 1-14.
}

\section{Astrid Nunn}

\section{(2) OpenEdition}

1 Journals

Édition électronique

URL : http://journals.openedition.org/abstractairanica/5691

DOI : 10.4000/abstractairanica.5691

ISSN : 1961-960X

Éditeur :

CNRS (UMR 7528 Mondes iraniens et indiens), Éditions de l'IFRI

\section{Édition imprimée}

Date de publication : 15 mai 2006

ISSN : 0240-8910

Référence électronique

Astrid Nunn, « «Rhodes, Cyprus and Southern Anatolia During the Archaic and Achaemenid Periods: The Ionian Question ». Colloquium Anatolicum III, 2004, pp. 1-14. », Abstracta Iranica [En ligne], Volume 27 | 2006, document 66, mis en ligne le 02 janvier 2007, consulté le 25 septembre 2020. URL : http:// journals.openedition.org/abstractairanica/5691; DOI : https://doi.org/10.4000/abstractairanica.5691

Ce document a été généré automatiquement le 25 septembre 2020.

Tous droits réservés 
« Rhodes, Cyprus and Southern Anatolia During the Archaic and Achaemenid Periods: The Ionian Question ». Colloquium Anatolicum III, 2004, pp. 1-14.

\section{Astrid Nunn}

De qui exactement parle-t-on avec le descriptif « ionien »? Chypre et l'Anatolie du sud sont considérées comme ioniennes dès l'époque assyrienne. À l'époque achéménide le concept de «ionien » s'étend à la Grèce. Les Ioniens sont dès lors les populations du front méditerranéen. Même les Louviens de Cilicie deviennent « ioniens», alors que la colonisation grecque n'a jamais eu beaucoup d'emprise sur eux. L'occidentalisation de la notion "Ionie» continuera à l'époque romaine et dépassera de loin la notion géographique de l'Ionie.

INDEX

Thèmes : 3.2.1. Elam 


\section{AUTEURS}

\section{ASTRID NUNN}

Université de Munich 